\title{
Exploring Curriculum Implementation in Response to Labour Markets
}

\author{
Mamosa Thaanyane ${ }^{1}$, Joseph Thabana ${ }^{2}$ \\ ${ }^{1,2}$ Department of Language and Social Education, National University of Lesotho, P.O. Roma 180, Maseru, Lesotho
}

\begin{abstract}
The Government of Lesotho has undertaken a number of policy initiatives in the past to improve education system to be accessible, relevant, efficient, and of the best quality. Contrary to these efforts, a gap continues to exist among curriculum, teaching, assessment and the world of work. This paper investigates the causes of the existing gap from secondary school teachers in Maseru district as implementers of curriculum. This qualitative study usedsemi-structured interviews with open-ended questions, with six teachers in Maseru district. These teachers were purposively selected to take part of the study. The results of the study revealed that the existence of the gap is due to the following factors: teachers' experience, focus on examination, poor education system and lack of coordination between stakeholders, school characteristics, and teachers' capacity. The results further show that teacher development in the form of workshops and teacher-refresher courses is not adequately offered to teachers.
\end{abstract}

Keywords: Curriculum implementation; labour markets; education; teaching; assessment and world of work

\section{Introduction}

The 21 st-century skills are at the centre of what an education system ought to be providing as its high priority. As Lesotho is not an exceptional, itseducation system aims at preparing learners for the world of work and further studies by changing curriculum to suit the educational goal (CAP 2009). Education system needs to provide students with hands-on learning that mirrors real-world problems and work opportunities in an interdisciplinary way as those skills cannot be taught in isolation. When learners possess these skills alongside content knowledge they are more likely to be successful in the workplace as well. Today's highly competitive job market has dramatically changed the rules for career success so much that people willing to work should meet demands of a job they are seeking (Lopez 2008). Preparing learners for the new workplace requires understanding the global economy as the new reality and finding out what businesses expect of workers in the new workplace as well as learners' ability to apply that knowledge at work. Therefore, teachers as curriculum implementersmust ensure that learners are aware of the basic premises and workplace competencies as they pursue their educational goals and career aspirations at school. For quality of education to be guaranteed, emphasis should be placed on the quality of teaching and learning in order to ensure impressiveness, efficiency and productivity of education. So, there is a need for schools to stress the need for changing curriculum content to be relevant to the culture and learner's needs as well as changing teaching and learning processes (UNESCO 2000).It continues to argue that teachers need to know that these skills are not taught rather modelled as they cannot be added to the curriculum with the hope that learners will learn them without the systematic planning. If teachers keep on narrowing their focusing on the cognitive skills only, the gap between education system and the world of work will still widen.

This brings us to claim that the concepts of teaching and learning should not run parallel but rather jointly as they go hand-in hand at same time, that is, because theyare two activities that are bound together (Amponsah 2016). There are some researchers who claim that, learning can sometimes take place without teaching because what is taught is not necessarily learned and what is learned is not necessarily the result of teaching as some people learn from experiences. As a planned action seeking to achieve educational goals, teaching and learning should be organised in a manner that results in learners' competence, ability to apply academic skills in a meaningful way, which also integrate career development (Utoware \& Kren-Ikidi 2013). The ability to bring together theoretical-conceptual learning in the classroom and the actual application in the workplace is the essential component in learners' making a successful transition to the world of work.Most policies encourage the use of learner-centred methods, because they allow learners to do most of the activities by themselves unlike teachercentred where a teachers do everything for the learners while expecting them to produce and understand the same material presented to them.

Even though teachers can prefer the use of learner-centred methods, change the function of content, create conducive learning environment, share power in their classrooms(Weimer 2012), the gap that exist between school and world of work still widens. There still are some challenges that hinder effective curriculum implementation which can emanate from teacher, learner and environment (Amponsah 2016). One challenge that we have seen in developing countries is lackof basic foundational skills that bridges school education to workplace. He further argues that learners are coming out of education system without them and are entering the labour market underequipped. This stresses the fact that teachers still use traditional teaching methods where they are the only expert with all knowledge to be transferred to the learner.In order to fight against the economic problem that most countries are facing, teachers have to align curriculum with assessment in such a way that it leads to development of 21 st century skills in learners.

Therefore, if these challenges are not addressed by the MoET, learners will leave schools having only cognitive skills which are inadequate for them to fit the world of work.

\section{Volume 8 Issue 4, April 2019 www.ijsr.net}




\section{International Journal of Science and Research (IJSR) \\ ISSN: 2319-7064}

ResearchGate Impact Factor (2018): 0.28 | SJIF (2018): 7.426

Hence this paper seeks to explore the cause of the existing gap between curriculum implementation and the world of work.

\section{Literature Review}

\subsection{Teacher's experience}

To make teacher's experience, relevant Mokhele (2011) posits that a teacher should be able to adequately select the learning experiences as well as content to attain skills and attitudes for learners. Moreover, he outlines that a teacher should also be able to organise and integrate learning with respect to teaching and learning process within the classroom. The teachers also have to employ classroom practices in such a way that they interact with learners and strategies they use should accomplish specific teaching tasks such as aligning them with assessment. Most importantly teachers have to communicate objectives to learners, allowing them to explain why such content is being learned. This should be the case because the curriculum implementation is the reaction between teachers, learners and other stakeholders (Asebiomo 2015).

In addition, Goe \& Stickler (2008) argue that better results are likely to be achieved in the classroom if at the outset of their lessons, teachers clearly define for learners what they are supposed to be learning and what acceptable performance looks like. According to BCTF (2017), there is also a need for instructional materials and clear helpful guidelines in relation to assessment and reporting.

\subsection{Focus on rote learning (Examination-oriented practices)}

One problem with incorporating skills into the school curriculum in developing counties is that it is difficult to reconcile with a heavy dependence on rote learning.Raselimo \& Mahao (2015) argue that if schools concentrate only on examinations only cognitive skills of their learners will be prepared, as paper and pencil examination do not accurately measure desirable competences and skills in learners. They further argue that when teachers' practices are examination-oriented, leaners are prepared to pass national examinations at the expense of acquiring skills. This means teachers still use traditional methods of assessment because they are examinationoriented which are not alone effective in measuring individual learning.

Pedagogical methods and approaches to teaching are also problematic in that, rather than being encouraged to engage critically with the subject matter at hand, learners are generally steered towards memorisation and rote-learning. Additionally, Loveluck (2012) adds that some schools have largely developed in response to an intense focus on examinations which pervades the entire education system. He further argued that teachers often rush through a great deal of content in each lesson in trying to cover all the material in a fact-heavy syllabus and not to lag behind other classes or schools. As a result learners have to memorise the same material and reproduce it in final exams administered simultaneously in all schools. The value attributed to examination results has come to be decisive for a learner's future opportunities. In many cases, learners therefore have neither academic nor physical stimulus and this lack of engagement has longer-term implications for their levels of concentration.

\subsection{Teachers' capability}

Students should be given an opportunity to work things out for themselves, while learning to respond to the differing skills and opinions of their peers.But teachers, working alone in their classrooms, choose what to teach and how to present it. Their choices derive from their knowledge of the subjects they teach, from their experiences in teaching the content, from their affection or distaste for topics and from their attitudes toward the students they face each day. Stressing on the need for quality in the production of teachers, the policy stated that no nation can be greater than the quality of her teachers. This means that teachers must be given quality education to enable them deliver the same quality of resources in their effort to teach learners. Invariably, it further implies that the teachers must also be highly qualified in their various occupational fields to justify the dream of the policy (Ordu 2013). The presence of qualified teachers will encourage the development thereby closing the bridge through which grasshoppers and interlopers use to gain entry into the programme.

\subsection{Poor education system and lack of coordination between stakeholders}

Education is key to achieving and sustaining the goals of any society that must develop its citizen (Asebiomo 2015). Developments in society and economy require that educational systems equip young people with newskills and competencies, which allow them to benefit from the emerging new forms of socialisation and tocontribute actively to economic development under a system where the main asset is knowledge. If education is placed in the heart of the country's social and economic development, full control of education would justify the state's dominant role in the instruction of its citizens. Controlling the curriculum and issuing specific lesson plans would show tight central control by the state and teachers would have little freedom to structure the progress of their classes or to cover material that is not included in the day's lesson plan. So, Government inspectors should frequently attend lessons, increasing pressure on teachers to adhere strictly to the given curriculum and projects (Loveluck 2012). This inability portrays failure of the entire education system and underlines an inherent mismatch of the type of education received to improve the employability of graduates in order to reduce unemployment (Nnadozie \& Kanwa 2013).

\subsection{Continuing professional development}

Incorporating skills in curriculum requires investing in the professional development of teachers to enable them to demonstrate the skills we expect them to inculcate in their learners. Then, the successful implementation of learnercentred approaches will result in the development of skills and knowledge of the teachers engage themselves in this alternative form of teaching and learning (Lin and Fishman 


\section{International Journal of Science and Research (IJSR) \\ ISSN: 2319-7064}

ResearchGate Impact Factor (2018): 0.28 | SJIF (2018): 7.426

2006).Curriculum and professional development designers need to provide different types of support for teachers with varying experiences and understanding of the underlying principles and structure of a curriculum. It is also advisable to use induction programmes for new teachers as they tend to impact on their long-life development.Hammerness, Darling-Hammond \& Bransford (2005) argue that global trend of teacher professionalism has encouraged teachers to develop as reflective practitioners with sufficient subjectmatter knowledge and curriculum, knowledge of learners and their development, and knowledge of effective teaching in collaborative settings. Some teachers claim that the continual use of mentors or resource person, face-to-face workshops, in-school or cluster support which provide inclass support for new teachers is also required (Dembele 2003). In addition, Ondigi (2012) argues that there should be additional educational programmes that are guaranteed for professional development growth to address different or new learning and teaching styles. He further puts that teachers should be provided with orientation and regular in-service to enhance learning of new changes in the teaching profession and requirement or demands of labour market. Support for teachers' professional development at the school level generally comes from either the school head, fellow teachers, or both.

There is a growing concern that schools are not producing citizens that are able to apply theirknowledge across a variety of contexts. The argument that in this information agetheknowledge, skills and behaviours needed for students to achieve at high levels require theability to access, interpret, analyse and use information for making decisions. It is hard to refute the claim that today's world requires thatcitizens and the workforce should possess more than basic reading and arithmetic skills (Nyabanyaba 2006). These skills and competencies, (referred to as $21 \mathrm{st}$ century skills and competencies), are more related to the needs of the emerging models of economic and social development than with those of the past century, which were suited to an industrial mode of production (Ananiadou \& Claro 2009).

It has been noticed that teachers' incompetency and unawareness of subject matter make them indecisive and avoid employing the appropriate methods of teaching in their classrooms (Dembele 2004). Teachers are expected to demonstrate specific skills, apply knowledge and possess professional qualities which will enable them prepare learners who can meet society's demands (Mokhele,2011).In the absence of evidence of the use of effective teaching practices, such measures offer little guidance on the nature of teacher training as test-based measures allow one to identify effective teachers on the job, but not to replicate them. If teachers are not provided with clear signals about legitimate ways in which to improve their practices, there is a danger that they will focus on examination instead of teaching test-taking skills at the cost of teaching other, more difficult to measure skill (Kane, Taylor, Tyler \& Wooden 2010).

\subsection{School characteristics}

Education should move from knowledge to skills and attitudes that advocate for learners' success and application of such skills responsive to change. Some schools which are results-oriented, (high-performing) ignore knowledge and understanding of global components such as economic systems and business practices. So, it makes learners leave school without alteration on knowledge and attitudes they had before.

Udoye and Ndum 2014) argue that any education system which does not equip its recipients with skills to be selfreliant is a faulty education system. For any curriculum to be successful requires that teachers be professionally wellprepared to satisfy the demands of the curriculum. In other words, educational administrators must be sure that teachers, prior to engaging themselves in teaching, possess sufficient pedagogical skills knowledge, as well as content knowledge, as to how to transform classroom into a place where learners can learn effectively.

\section{Purpose}

The main purpose of this study was to explore the impact of curriculum implementation in response to labour-markets. Moreover, the study sought to find the challenges associated with the widening gap between curriculum implementation and the world of work. The study focused on secondary school teachers in Maseru district in Lesotho as implementers of curriculum. Teachers are expected to demonstrate specific skills, apply knowledge and possess professional qualities which will enable them prepare learners who can meet society's demands (Mokhele,2011).

\section{Methodology}

This was a qualitative study which used individual interviews with open-ended questions. The questions were meant to explore challenges that widens the gap between and curriculum implementation and the workplace.Six teachers were individually interviewed. These teachers were purposively selected to be part of the study.

\section{Results and Discussion}

Data was collected through individual interviews with teachers using semi structured. When asked whether teachers' educational attainment is a challenge that enlarges the gap that exist between school and world of work, most teachers agreed with it. They further their point that there are uncertificated teachers that are not professionally trained and faking existing professional for the purpose of gaining accreditation status. This widens the gap between curriculum implementation and the world of work because for any curriculum to be successful requires that teachers be professionally well-prepared to satisfy the demands of the curriculum. In other words, schools must be sure that teachers, prior to engaging themselves in teaching, possess sufficient pedagogical skills knowledge, as well as content knowledge, as to how to transform classroom into a place where learners can learn effectively. In support to this,

Volume 8 Issue 4, April 2019 www.ijsr.net 


\section{International Journal of Science and Research (IJSR) \\ ISSN: 2319-7064}

ResearchGate Impact Factor (2018): 0.28 | SJIF (2018): 7.426

Mokhele (201) posits that a teacher should be able to adequately select the learning experiences as well as content to attain skills and attitudes for learners that will prepare them for the world outside school. Moreover, he outlines that a teacher should also be able to organise and integrate learning with respect to teaching and learning process within the classroom.

Some skills are likely to become obsolete with time which informs a need for retraining of teachers whose skills will turn out to be unmarketable anymore. It is on the basis of this that teachers will be able to develop the conceptual skills for designing and conducting their classroom instructions if offered continuing professional development (Kirkpatrick \& Zang 2011). It is also supported by Lin and Fishman (2006) that for a successful implementation, teachers need in-service training to inform them about the newest methods encouraged by educational reforms to link curriculum implementation with the world of work. Some claim that the continual use of mentors or resource person, face-to-face workshops, in-school or cluster support, which provide in-class support for new teachers, is also required to help in teachers' incompetency and unawareness of subject matter that make them indecisive and avoid employing the appropriate methods of teaching in their classrooms. In addition, Ondigi (2012) argues that there should be additional educational programmes that are guaranteed for professional development growth to address different or new learning and teaching styles. He further puts that teachers should be provided with orientation and regular in-service to enhance learning of new changes in the teaching profession and requirement or demands of labour market. Support for teachers' professional development at the school level generally which comes from either the school head, fellow teachers can help teachers in implementing curriculum relating it to the world outside.

Another challenge is poor education system. Teachers also agreed that the gap exists as a result of poor education system and poor coordination with stakeholders. Education needs to provide learners with social value and attitudes that they can benefit from it. Some teachers agreed that poor education system is a challenge that make learners not fitting into workplace. It portrays failure of the entire educational system and underlines on inherent mismatch between the type of education received to improve the employability of graduates and reduces the existing gap.

In relation to teachers' capability, teachers showed that it becomes a challenge that widens the gap between the school environment and the world of work. They further put that as teachers, they must focus in preparing learners not only in mastery of content knowledge but also on employment skills including critical thinking, problem-solving collaboration and creativity. Hammerness, Darling-Hammond, \& Bransford,2005) support it that teachers' capacity to plan an instruction so that it meets the needs of the learner and the demands of the content shows the competence a teacher possess.

One other challenge teachers pointed out is that of schools focusing on rote learning or are examination-oriented. They argued that even if they would like to use strategies that would prepare learners for the world outside schools, some administrations or principals want to be recognised as outstanding performing schools. Hence prepare learners to achieve examinations goals. This goes along with what Raselimo and Mahao (2015) outlined, that if schools concentrate only on examinations only cognitive skills of their learners will be prepared, as paper and pencil examination do not accurately measure desirable competences and skills in learners. As result, learners will not be equipped with skills that bridges schools with workplace. They further argued that when teachers' practices are examination-oriented, leaners are prepared to pass national examinations at the expense of acquiring skills. This means teachers still use traditional methods of assessment because they are examination-oriented which are not alone effective in measuring individual learning. Teachers need to be skillful in order to use curriculum effectively.

\section{Conclusion}

As a result of a highly competitive job market which has dramatically changed the rules for career success, people should meet demands of a job they are seeking. Therefore,school education. There still are some challenges that hinder effective curriculum implementation which can emanate from teacher, learner and environment system needs to provide students with hands-on learning that mirrors real-world problems and work opportunities in an interdisciplinary way as those skills cannot be taught in isolation. It has been discovered that the existence of the gap is due to different factors including, teacher educational attainment, poor education system and teachers' capacity. The results further show that teacher development in the form of workshops and teacher-refresher courses is lacking.

\section{References}

[1] Amponsah, S. 2014. The use of student-teams achievements division as a teaching strategy in English first additional language in KwaZulu-Natal. Doctoral degree thesis, University of South Africa

[2] Ananiadou, K. \& M. Claro. 2009.21st Century Skillsand Competences for New Millennium Learners in OECDCountries, OECD Education Working Papers, No. 41,OECD Publishing.

[3] Asebiomo, A.M. 2015. Moving With Global Trends in Curriculum Innovation: Mitigating the Challenges of Curriculum Implementation for Effective Teaching and Learning in Nigeria. International Journal of Managerial Studies and Research (IJMSR) (3)1:26-33.

[4] BCTF. 2017. Curriculum Change and Implementation Survey. Retrieved from https://bctf.ca/uploadedFiles/Public/issues/curriculum/s urvey/2017Survey.pdf.

[5] Curriculum and Assessment Policy. 2009. Education for individual and social development. Ministry of Education and Training: Lesotho

[6] Dembélé, M. (2004) Pedagogical renewal: The critical role of teacher professional development. ADEA Newsletter, 16(1), 15-16

\section{Volume 8 Issue 4, April 2019 www.ijsr.net}




\section{International Journal of Science and Research (IJSR) \\ ISSN: 2319-7064}

ResearchGate Impact Factor (2018): 0.28 | SJIF (2018): 7.426

[7] Goe, 1\& Croft, L. (2009). Methods of evaluating teacher effectiveness. Washington, DC: National Comprehensive Center for Teacher Quality

[8] Hammerness, K., Darling-Hammond, L., \& Bransford, J. 2005. How teachers learn anddevelop. In L. DarlingHammond, \& J. Bransford, (Eds.), Preparing teachers for a changing world: what teachers should learn and be able to do, 358-389). SanFrancisco: Jossey-Bass.

[9] Kirkpatrick,R. \&Zang,Y. 2011. The negative influences of exam-oriented education on Chinese High school students: backwash from classroom to child. Language Testing in Asia, 1(3); 36-45.

[10]Lin, H \& Fishman, B. 2006.Exploring the relationship between teachers experience with curriculum and understanding of implicit unit structures.U.S.A: University of Michigan.

[11]Lopez, H. 2008. Business education, Internships and students transition to work - Are students meeting employers' expectations? Touchstone

[12] Loveluck, L. 2013.Education in Egypt: Key Challenges. Background Paper. Egypt.

[13] Ondigi, SR. 2012. Role of Education in prompting entrepreneurial skills through classroom practices: teacher training in the Kenyan Universities. International Review of Social Sciences and Humanities, 3(2); 125-138.

[14] Ordu, P. 2012. Introduction to Vocational Education. Omoku: Jef Computers Services.

[15] Raselimo, M \& Mahao, M. 2015. The Lesotho curriculum and assessment policy: opportunities and threats. South African Journal of Education 35(1): 1-12.

[16] Rowe, AD \& Zegwaard KE. 2017. Developing graduate employability skills and attributes: Curriculum enhancement through work-integrated learning. AsiaPacific Journal of Cooperative Education (18)2, 87-99.

[17] UNESCO. 2000. Education for All: From Jomtien to Dakar and beyond. Washington, D.C.: World Bank

[18] Utoware, JDA \& Kren-Ikidi, PC. 2013. New Technologies in Business Education for Instruction and Practice: Imperatives for Quality Assurance. American International Journal of Contemporary Research 3( 9); 124

[19] Weimer, M. 2013. Learner-centred teaching: five key changes to practice. Jossey-Boss. San Francisco

Volume 8 Issue 4, April 2019 www.ijsr.net 